\title{
Differential Responses of Antioxidants, Abscisic Acid, and Auxin to Deficit Irrigation in Two Perennial Ryegrass Cultivars Contrasting in Drought Tolerance
}

\author{
Xunzhong Zhang', Erik H. Ervin, and Yiming Liu \\ Department of Crop and Soil Environmental Sciences, Virginia Polytechnic Institute and State \\ University, Blacksburg, VA 24061 \\ Guofu Hu \\ Department of Crop and Soil Environmental Sciences, Virginia Polytechnic Institute and State \\ University, Blacksburg, VA 24061; and College of Animal Science and Technology, Northeast \\ Agricultural University, Harbin, Heilongjiang, People's Republic of China 150030 \\ Chao Shang, Takeshi Fukao, and Jasper Alpuerto \\ Department of Crop and Soil Environmental Sciences, Virginia Polytechnic Institute and State \\ University, Blacksburg, VA 24061
}

\begin{abstract}
Additional Index words. indole-3-acetic acid, lipid peroxidation, superoxide dismutase, grass
Abstract. Water deficit is a major limiting factor for grass culture in many regions with physiological mechanisms of tolerance not yet well understood. Antioxidant isozymes and hormones may play important roles in plant tolerance to water deficit. This study was designed to investigate antioxidant enzymes, isozymes, abscisic acid (ABA), and indole-3acetic acid (IAA) responses to deficit irrigation in two perennial ryegrass (Lolium perenne $\mathrm{L}$.) cultivars contrasting in drought tolerance. The plants were subjected to well-watered $\{100 \%$ container capacity, $34.4 \% \pm 0.21 \%$ volumetric moisture content (VWC), or deficit irrigation [30\% evapotranspiration (ET) replacement; $28.6 \% \pm 0.15 \%$ to $7.5 \% \pm$ $0.12 \% \mathrm{VWC}]\}$ conditions for up to 8 days and rewatering for 4 days for recovery in growth chambers. Deficit irrigation increased leaf malondialdehyde (MDA) content in both cultivars, but drought-tolerant Manhattan-5 exhibited lower levels relative to drought-sensitive Silver Dollar. Superoxide dismutase (SOD) activity declined and then increased during water-deficit treatment. 'Manhattan-5' had higher SOD activity and greater abundance of SOD1 isozyme than 'Silver Dollar' under water deficit. Deficit irrigation increased catalase (CAT) and ascorbate peroxidase (APX) activity in 'Manhattan-5', but not in 'Silver Dollar'. 'Manhattan-5' had higher CAT, APX, and peroxidase (POD) activity than 'Silver Dollar' during water limitation. Deficit irrigation increased mRNA accumulation of cytosolic cupper/zinc SOD $(C y t C u / Z n S O D)$, whereas gene expression of manganese SOD (Mn $S O D)$ and peroxisome $A P X(p A P X)$ were not significantly altered in response to deficit irrigation. No differences in $C y t$ $C u / Z n S O D, M n S O D$, and $p A P X$ gene expression were found between the two cultivars under deficit irrigation. Water limitation increased leaf ABA and IAA contents in both cultivars, with Silver Dollar having a higher ABA content than Manhattan-5. Change in ABA level may regulate stomatal opening and oxidative stress, which may trigger antioxidant defense responses. These results indicate that accumulation of antioxidant enzymes and ABA are associated with perennial ryegrass drought tolerance. Activity and isozyme assays of key antioxidant enzymes under soil moisture limitation can be a practical screening approach to improve perennial ryegrass drought tolerance and quality.
\end{abstract}

Water deficit is a major limiting factor for grass culture in many regions. As a consequence of climate change, water deficit may have an increasingly negative impact on grass quality and persistence (Zhang et al., 2012). Plants have developed various physiological defense systems to cope with abiotic stress, such as antioxidant defenses, hormonal regulation, osmotic adjustment, and saturation level of cell membrane lipids (Huang et al., 2014a). Antioxidants and hormones are some of the most important metabolic defenses against drought stress (Zhang et al., 2012).

Water deficit may inhibit photosynthesis and cause an energy imbalance so that the energy absorbed through the light-harvesting complex exceeds what can be dissipated or

Received for publication 7 July 2015. Accepted for publication 6 Aug. 2015. ${ }^{1}$ Corresponding author. E-mail: xuzhang@vt.edu. transduced by photosystem II (Zhang and Ervin, 2008). Excess energy may be directed to oxygen $\left(\mathrm{O}_{2}\right)$ and result in the accumulation of toxic reactive oxygen species (ROS) (Huang et al., 2014a; Zhang and Ervin, 2004). To limit oxidative damage under stress conditions, plants have developed a series of detoxification systems that break down the highly toxic ROS (Wang et al., 2012; Zhang and Kirkham, 1996; Zhang et al., 2012). Superoxide dismutase has been considered as the first line of defense against ROS by dismutating the superoxide anion to hydrogen peroxide $\left(\mathrm{H}_{2} \mathrm{O}_{2}\right)$, which is finely regulated by CAT and an array of PODs localized in almost all compartments of the plant cell, such as APX (Blokhina et al., 2003). Four kinds of SOD have been found in plants depending on their metal cofactor: the copper/zinc type (Cu/Zn SOD), manganese type (MnSOD), the iron type (FeSOD), and the nickel type (NiSOD), which are localized in mitochondria, 
chloroplasts, cytosol, and peroxisomes (Hu et al., 2012). All these isoforms protects cellular molecules from damage caused by ROS. Ascorbate peroxidase detoxifies $\mathrm{H}_{2} \mathrm{O}_{2}$ using ascorbate as a substrate and its isoforms are active in chloroplasts, cytosol, peroxisomes, and mitochondria (Mittler et al., 2004). Previous studies have indicated that higher activity levels of antioxidant enzymes may contribute to greater drought tolerance by increasing a plant's protective capacity against oxidative damage (Lu et al., 2008; Xu et al., 2011; Zhang and Ervin, 2004; Zhang et al., 2012). Water deficit-induced oxidative stress has been reported in perennial ryegrass (Krishnan et al., 2013; Yu et al., 2013), creeping bentgrass [Agrostis stolonifera L. (DaCosta and Huang, 2007; Zhang and Ervin, 2004)], tall fescue [Festuca arundinacea Schreb. (Man et al., 2011; Zhang et al., 2012)], and kentucky bluegrass [Poa pratensis L. (Jiang and Huang, 2001; Xu et al., 2011)]. Krishnan et al. (2013) noted that APX and POD activity increased in response to drought stress in perennial ryegrass. Variations in antioxidant enzyme activities have been associated with differences in drought tolerance of grass cultivars (Man et al., 2011). Although excessive accumulation of ROS results in cellular damage and breakdown of macromolecules, ROS are signaling molecules that trigger various adaptive responses to abiotic and biotic stresses. Some ROS-scavenging enzymes such as SOD and APX are found in multiple subcellular compartments, contributing to the tight regulation of ROS levels in each organelle under stress conditions (Mittler et al., 2004). Thus, changes in the amount of particular isoforms of each antioxidant enzyme can be more important than alterations in the total activity (Mullineaux and Creissen, 1997). Pinhero et al. (1997) have suggested that synthesis of new antioxidant enzyme isoforms could be more beneficial for antioxidant metabolism than enhancement of the activity. The induction of specific isozymes in many plants has been recognized as biomarkers of various environmental stresses (Kim et al., 2007). Limited research has focused on the gene expression patterns in conjunction with the underlying enzyme activity and isozyme alterations in cultivated grasses. Elucidating the association of antioxidant enzyme activity and gene expression in cultivars with contrasting drought tolerance would contribute to an enhanced understanding of molecular mechanisms of antioxidant defense systems for drought tolerance of cultivated grasses.

It has been reported that alteration in hormone metabolism is associated with plant tolerance to abiotic stress (Huang et al., 2014a; Man et al., 2011; Zhang et al., 2009). Abscisic acid and IAA are hormones that mediate signaling events involved in plant adaptation to stress and senescence. IAA is the primary auxin in the majority of plant species. There is evidence showing that adaptation to drought stress is accompanied by an increase in IAA content (Krishnan and Merewitz, 2015). ABA plays a regulatory role in controlling stomatal aperture under drought stress (Strivastava, 2002). Rapid ABA accumulation has been observed when plants are subjected to drought, salinity, and extreme temperatures (Xiong et al., 2002). However, the interrelations between the changes in hormone (IAA and ABA) metabolism and the development of adaptation to drought stress in perennial grass species are largely unknown. Furthermore, little has been reported on antioxidant responses in relation to changes in ABA and IAA levels during deficit irrigation and postdrought recovery in perennial ryegrass. Perennial ryegrass is a cool-season species widely used for golf courses, commercial landscapes, and pastures in temperate climates. Drought stress is a major factor limiting the growth and persistence of perennial ryegrass in many regions (Yu et al., 2013). The practice of deficit irrigation can be done so as to maintain acceptable turf quality while conserving irrigation water (Huang et al., 2014a). The mechanisms of drought tolerance associated with antioxidant and hormone metabolism in cool-season perennial grass species

Table 1. Real-time polymerase chain reaction primers used for analysis of antioxidant gene expression in two perennial ryegrass cultivars contrasting in drought tolerance.

\begin{tabular}{llc}
\hline Primer/gene name & \multicolumn{1}{c}{ Sequence $\left(5^{\prime}-3^{\prime}\right)$} & Annealing temp $\left({ }^{\circ} \mathrm{C}\right)$ \\
\hline eIF $1 A$-forward & & 55 \\
$e I F 1 A$-reverse & AACTCAACTTGAAGTGTTGGAGTG & 55 \\
$p A P X$-forward & AGATCTGGTCCTGGAAAGAATATG & 55 \\
$p A P X$-reverse & CCTGAAAGGTCTGGGTTTGA & 55 \\
$C y t C u / Z n S O D$-forward & TCCTTGGCATAAAGGTCCAC & 50 \\
$C y t C u / Z n S O D$-reverse & GACACMACAAATGGHTGCAT & 50 \\
$M n S O D$-forward & TCATCBGGATCGGCATGGACAAC & 55 \\
$M n S O D$-reverse & CAGRGBGCCATCAAGTTCAACG & 55
\end{tabular}

${ }^{\mathrm{z} e I F 1 A}=$ eukaryotic initiation factor 4 alpha; $p A P X=$ peroxisome ascorbate peroxidase; $C y t C u / Z n S O D=$ cytolic cupper/zinc superoxide dismutase; $M n S O D=$ manganese superoxide dismutase.

Table 2. Parameters for analysis of leaf indole-3-acetic acid (IAA), $\mathrm{C}^{13}$-labeled IAA, and abscisic acid (ABA) of two perennial ryegrass cultivars contrasting in drought tolerance using liquid chromatography-mass spectrometry.

\begin{tabular}{|c|c|c|c|c|c|c|}
\hline Analyte & Retention time (min) & Precursor ion & Product ion & Application & Collision energy (V) & Mode \\
\hline IAA & 3.6 & 176.1 & 130.2 & Quantitative & 12 & + \\
\hline $\mathrm{C}^{13}$-labeled IAA & 3.6 & 182.1 & 136.2 & Quantitative & 12 & + \\
\hline \multirow[t]{2}{*}{$\mathrm{ABA}$} & 4.2 & 265.2 & 247.2 & Quantitative & 0 & + \\
\hline & & & 229.2 & Qualitative & 4 & + \\
\hline
\end{tabular}




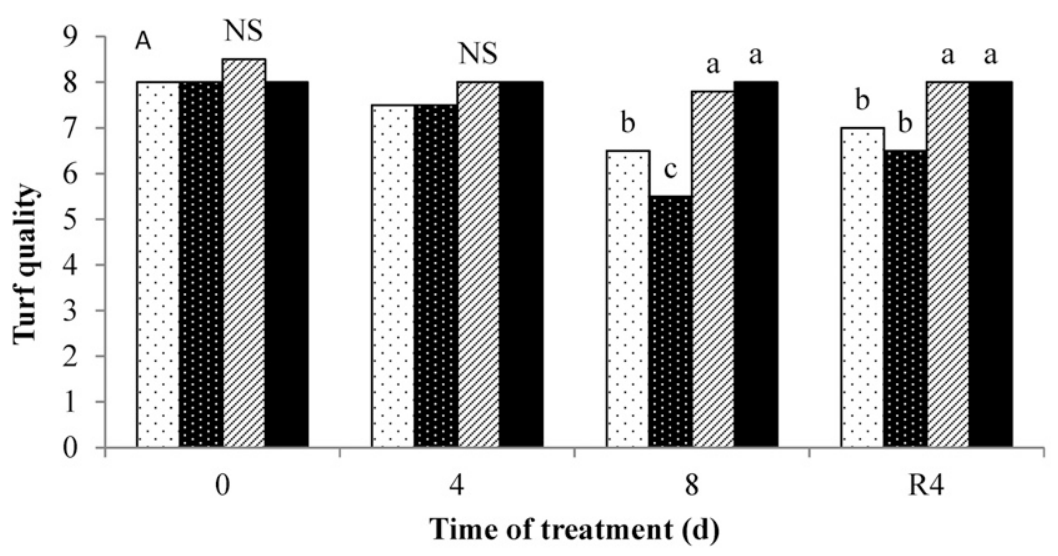

๑Manhattan5-D a SilverDollar-D $\square$ Manhattan5-W $\square$ SilverDollar-W

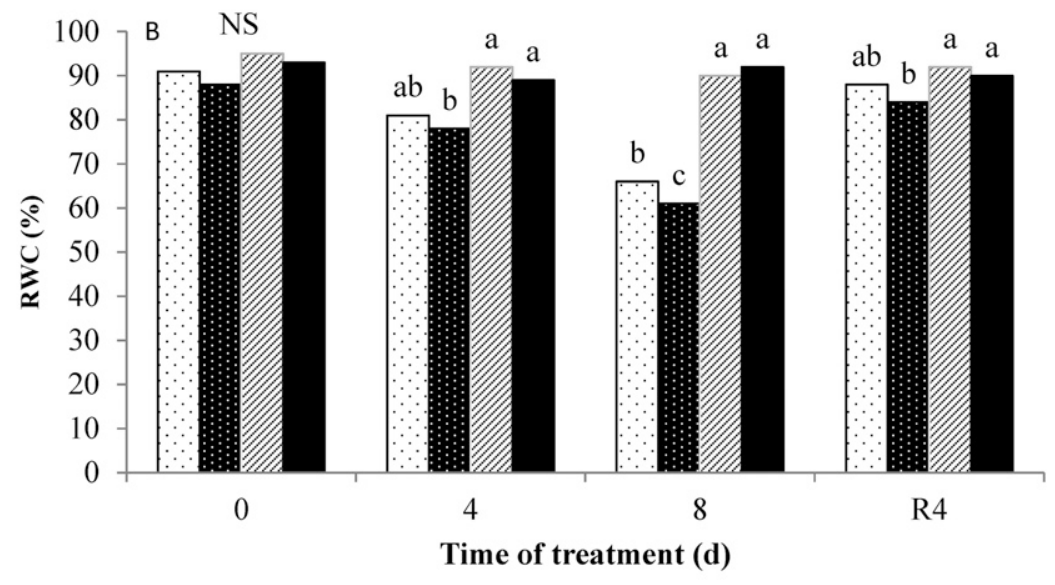

๑Manhattan5-D a SilverDollar-D \Manhattan5-W a SilverDollar-W

Fig. 1. Quality [1-9 visual scale, $9=$ the best (A)] and leaf relative water content [RWC (B)] of two perennial ryegrass cultivars (drought-tolerant Manhattan-5 and drought-sensitive Silver Dollar) at days 0,4 , and 8 of deficit irrigation and recovery at day 4 following rewatering (R4). Bars marked with different letters at a given sampling date are not significantly different based on Fisher's protected least significance difference test at $P=0.05$ ( $\mathrm{Ns}=$ not significant). Manhattan5-D and Manhattan5-W indicate 'Manhattan-5' under deficit irrigation and well-watered conditions, respectively; SilverDollar-D and SilverDollar-W indicate 'Silver Dollar' under deficit irrigation and well-watered conditions, respectively.

are not well understood. Few studies have reported on drought stress-induced changes in the isoform patterns of antioxidant enzymes and gene expression in cool-season grasses. Understanding the physiological mechanisms of grass responses to deficit irrigation is important for breeders to develop drought-tolerant cultivars and for practitioners to improve grass quality under soil moisture limited environments. The objectives of this study were to compare antioxidant enzyme activities, related isozymes, gene expression, and hormone accumulation of two perennial ryegrass cultivars Manhattan-5 (drought tolerant) and Silver Dollar (drought intolerant), allowing us to determine key physiological and molecular traits associated with drought tolerance in this commercially important species.

\section{Materials and Methods}

Plant materials and growth conditions. The experiment was conducted from 28 Aug. to 30 Sept. 2014 (Expt. 1) and repeated from 5 Oct. to 8 Nov. 2014 (Expt. 2). Seeds of two perennial ryegrass cultivars (Manhattan-5 and Silver Dollar) obtained from Turf Merchants (Albany, OR) and Rose Agri-Seed (Canby, OR), respectively, were planted in plastic pots $(16 \mathrm{~cm}$ diameter, $15 \mathrm{~cm}$ deep) filled with silt loam soil (fineloamy, mixed mesic Typic Hapludult) mixed with a medium particle size sand $(2: 1, \mathrm{v} / \mathrm{v})$ at a seeding rate of $30 \mathrm{~g} \cdot \mathrm{m}^{-2}$ pure live seeds on 28 Aug. 2014. Cultivar Manhattan-5 is a relatively drought tolerant and Silver Dollar is drought sensitive based on the results from a previous study (Yu, 2013). Plants were cultured in a growth chamber with temperatures at (mean $\pm \mathrm{SD}) 20 \pm 0.8 / 16 \pm 0.6{ }^{\circ} \mathrm{C}$ (day/night), $70 \% \pm 8 \%$ relative humidity, 14-h photoperiod, and photosynthetically active radiation at $400 \pm 10 \mu \mathrm{mol} \cdot \mathrm{m}^{-2} \cdot \mathrm{s}^{-1}$. Plants were fertilized at $2.5 \mathrm{~g} \cdot \mathrm{m}^{-2}$ nitrogen (N) per month, trimmed to $10 \mathrm{~cm}$ weekly, and irrigated by hand until water drained from bottom of the pots, three times per week. For Expt. 2, the grass seeds were planted on 5 Oct. 2014 and seedlings were grown under the same environmental conditions as Expt. 1.

Drought Stress treatments. Plants were grown in growth chambers for $21 \mathrm{~d}$. At day 21 [18 Sept. 2014 (Expt. 1)], pots were irrigated to field capacity and weighed after drainage ceased. Next, the two cultivars were subjected to two soil moisture regimes: well-watered and deficit irrigation. There were four replicates with each replicate being placed in a separate growth chamber. Four growth chambers were used. For the well-watered treatment, plants were irrigated daily and maintained at field capacity (Manhattan5-W and SilverDollar-W). For deficit irrigation treatment, the grasses were irrigated daily at $30 \%$ of gravimetrically measured ET loss (Manhattan5-D and SilverDollar-D).

Plants were kept under soil moisture limitation for $8 \mathrm{~d}$ from 18 to 26 Sept. 2014 (Expt. 1). Next, all pots were irrigated to field capacity, and the deficit-irrigated grasses were allowed to recover for $4 \mathrm{~d}$ from 26 to 30 Sept. 2014. Fresh leaf samples were collected on days $0,4,8$, and R4 ( $4 \mathrm{~d}$ recovery following rewatering) for analysis of MDA, antioxidant enzymes, and hormones. Leaf samples were frozen in liquid $\mathrm{N}_{2}$ and kept at $-80{ }^{\circ} \mathrm{C}$ before final analysis. The experiment was repeated from 5 Oct. 2014 to 8 Nov. 2014, with water-deficit treatment from 28 Oct. to 4 Nov. (Expt. 2).

SoIL MOISTURE CONTENT. Soil moisture content was measured with a soil moisture sensor (ThetaProbe; Delta-T Devices, Cambridge, UK) every other day. Moisture retention at -0.01 and $-1.5 \mathrm{MPa}$ of the soil was estimated before treatment initiation with a standard pressure plate method (Klute, 1983). Three samples per matric potential were used.

Grass QUALITY AND PHOTOCHEMICAL EFFICIENCY [PE (Fv/ FM)]. Grass quality was visually rated on a scale from 1 to 9 


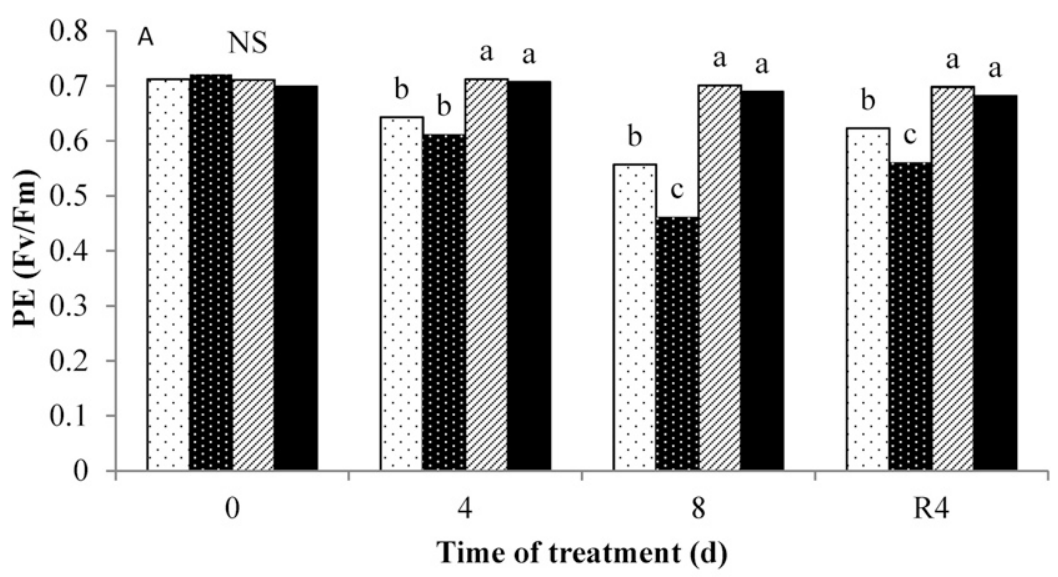

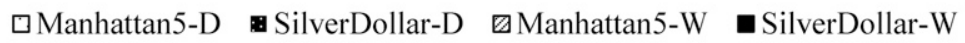

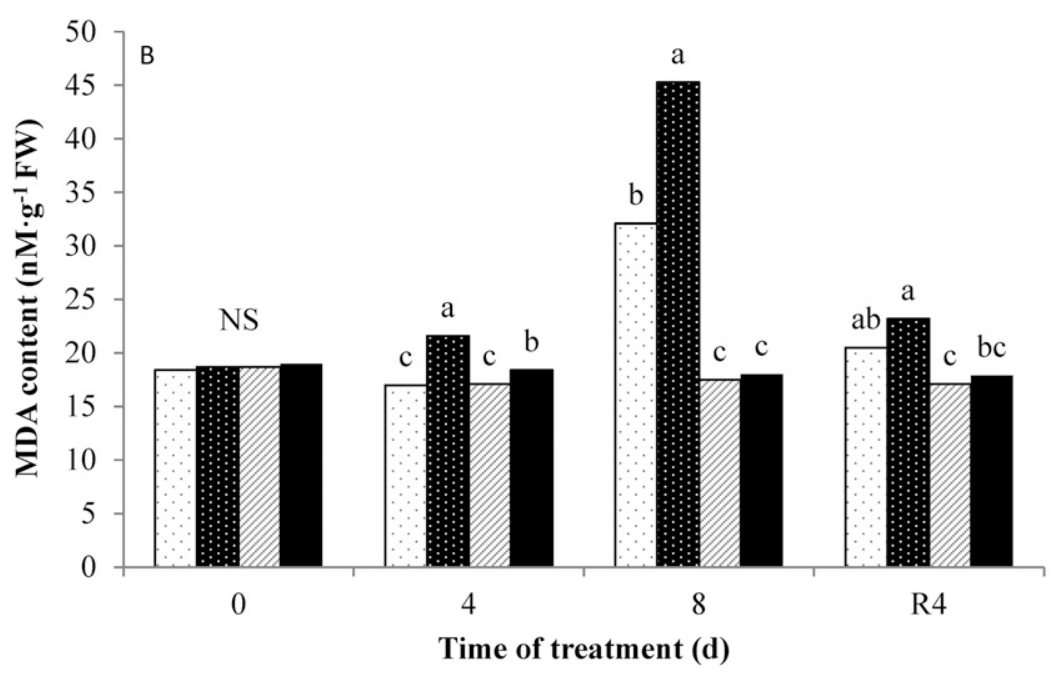

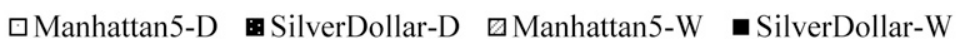

Fig. 2. Photochemical efficiency [PE (A)] and malondialdehyde [MDA (B)] of two perennial ryegrass cultivars (drought-tolerant Manhattan-5 and drought-sensitive Silver Dollar) at days 0, 4, and 8 of deficit irrigation and recovery at day 4 following rewatering (R4). Bars marked with different letters at a given sampling date are not significantly different based on Fisher's protected least significance difference test at $P=0.05$ ( Ns $=$ not significant). Manhattan5-D and Manhattan5-W indicate 'Manhattan-5' under deficit irrigation and well-watered conditions, respectively; SilverDollar-D and SilverDollar-W indicate 'Silver Dollar' under deficit irrigation and well-watered conditions, respectively.

based on leaf color, uniformity and density, with 1 indicating completely dead or brown leaves, 6 representing minimum acceptability, and 9 indicting turgid and green leaves, with optimum canopy uniformity and density. Canopy PE was measured using a chlorophyll fluorometer (OS-50II; OpticScience, Tyngsboro, MA) as described by Zhang et al. (2009).

LEAF RELATIVE WATER CONTENT (RWC). Leaf RWC was determined using the method described by DaCosta and Huang (2007) with minor modifications. Briefly, leaf samples $(\approx 100 \mathrm{mg})$ were collected and weighed immediately to determine fresh weight (FW). The leaf sample was cut into $\approx 5 \mathrm{~mm}$ sections and placed in a $2-\mathrm{mL}$ microcentrifuge tube with $1.8 \mathrm{~mL}$ deionized (d.i.) $\mathrm{H}_{2} \mathrm{O}$. After $\approx 15 \mathrm{~h}$ at $4{ }^{\circ} \mathrm{C}$, the leaf sample was blotted dry and weighed immediately to determine turgid weight (TW). The leaf tissue was then dried at $70{ }^{\circ} \mathrm{C}$ for $72 \mathrm{~h}$ to determine dry weight (DW). Leaf RWC was calculated following the equation: RWC $(\%)=[(\mathrm{FW}-\mathrm{DW}) /$ $(\mathrm{TW}-\mathrm{DW})] \times 100$.

LEAF MDA. Membrane lipid peroxidation was determined based on MDA content. The MDA was measured according to Hodges et al. (1999). Leaf samples (0.25 g) were homogenized in $10 \mathrm{~mL} 10 \%$ trichloroacetic acid (TCA) and centrifuged at $12,000 g_{\mathrm{n}}$ for $20 \mathrm{~min}$. Then $2 \mathrm{~mL} 0.6 \%$ thiobarbituric acid in $10 \%$ TCA was added to $2 \mathrm{~mL}$ supernatant. The mixture was heated in boiling water for 30 min then quickly cooled in an ice bath. After centrifugation at $1600 g_{\mathrm{n}}$ for $10 \mathrm{~min}$, the absorbance of the mixture at 450,532 , and $600 \mathrm{~nm}$ was determined. The concentration of MDA was calculated using MDA's extinction coefficient of $155 \mathrm{~mm}^{-1} \cdot \mathrm{cm}^{-1}$.

LEAF PROTEIN AND ANTIOXIDANT ENZYME ACTIVITY. Frozen leaf samples $(0.25 \mathrm{~g})$ were ground in liquid $\mathrm{N}_{2}$ and extracted in $3 \mathrm{~mL}$ of ice-cold $50 \mathrm{mmol}$ sodium phosphate buffer $(\mathrm{pH}=7.0)$ containing $0.2 \mathrm{~mm}$ ethylenediaminetetraacetic acid (EDTA) and 1\% polyvinylpyrrolidone in an ice-water bath. The homogenate was centrifuged at $12,000 g_{\mathrm{n}}$ for $20 \mathrm{~min}$ at $4{ }^{\circ} \mathrm{C}$. Supernatant was used to measure SOD, CAT, POD, and APX activities. Protein content was determined based on Bradford (1976).

Superoxide dismutase activity was determined by measuring its ability to inhibit the photochemical reduction of nitro blue tetrazolium (NBT) according to the method of Giannopolitis and Ries (1977) with minor modifications. The reaction solution $(1 \mathrm{~mL})$ contained $50 \mathrm{~mm}$ phosphate buffer $(\mathrm{pH}=$ 7.8), 0.1 mм EDTA, $13 \mathrm{~mm}$ methionine, $65 \mu \mathrm{M}$ NBT, $1.3 \mu \mathrm{M}$ riboflavin, and $30 \mu \mathrm{L}$ SOD extract. A solution containing no enzyme solution was used as the control. Test tubes were irradiated under fluorescent lights $\left(60 \mu \mathrm{mol} \cdot \mathrm{m}^{-2} \cdot \mathrm{s}^{-1}\right)$ at $25{ }^{\circ} \mathrm{C}$ for $10 \mathrm{~min}$. The absorbance of each solution was measured at $560 \mathrm{~nm}$ using a spectrophotometer, and one unit of enzyme activity was defined as the amount of enzyme that would inhibit $50 \%$ of NBT photoreduction.

Activities of CAT and POD were determined using the method of Chance and Maehly (1955) with modifications. For CAT, the reaction solution $(1 \mathrm{~mL})$ contained $50 \mathrm{~mm}$ phosphate buffer $(\mathrm{pH}=7.0), 15 \mathrm{~mm} \mathrm{H}_{2} \mathrm{O}_{2}$, and $30 \mu \mathrm{L}$ of extract. The reaction was initiated by adding the enzyme extract. Changes in absorbance at $240 \mathrm{~nm}$ were read in 1 min using a spectrophotometer $\left(\epsilon=39.4 \mathrm{M}^{-1} \cdot \mathrm{cm}^{-1}\right)$. For POD analysis, the reaction mixture contained $1 \mathrm{~mL} 50 \mathrm{~mm}$ phosphate buffer $(\mathrm{pH}=7.0)$, $0.95 \mathrm{~mL} 0.2 \%$ guaiacol solution, and $30 \mu \mathrm{L}$ enzyme extract. The reaction was started with $1 \mathrm{~mL} 0.3 \% \mathrm{H}_{2} \mathrm{O}_{2}$. Reading at 470 $\mathrm{nm}$ was recorded for $1 \mathrm{~min}\left(\epsilon=26.6 \mathrm{~mm}^{-1} \cdot \mathrm{cm}^{-1}\right)$.

The activity of APX was detected using the method of Zhang et al. (2005). The reaction solution $(1 \mathrm{~mL})$ contained $50 \mathrm{~mm}$ phosphate buffer $(\mathrm{pH}=7.0), 0.5 \mathrm{~mm}$ ascorbate, $0.1 \mathrm{~mm}$ EDTA, 


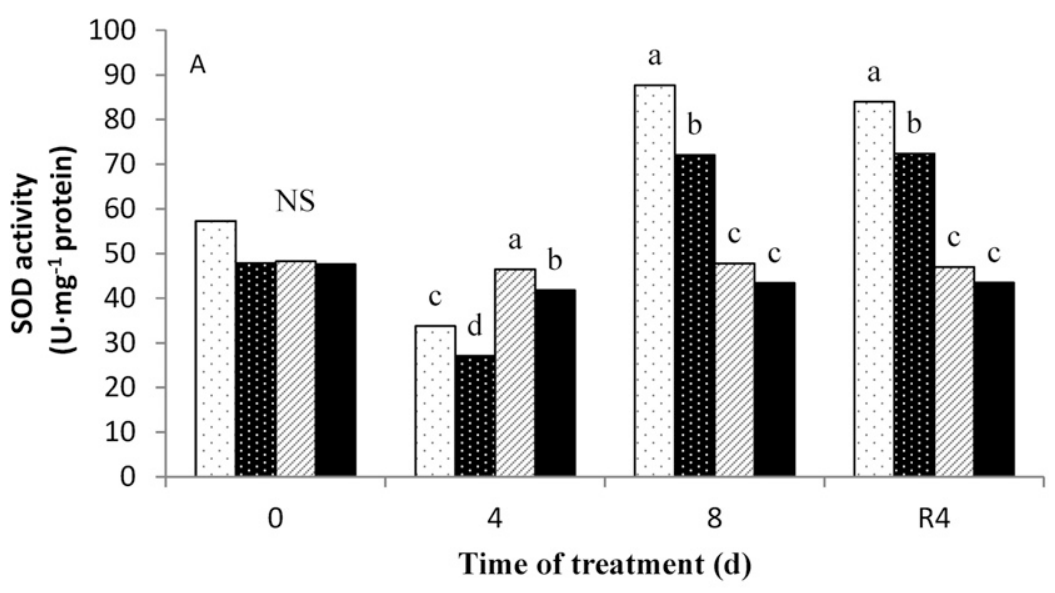

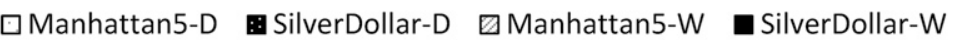

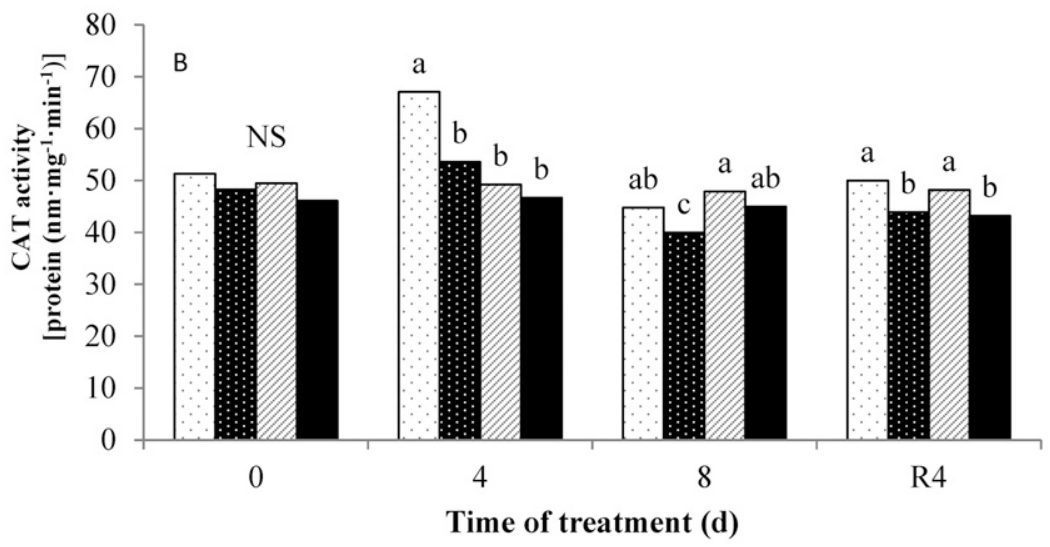

$\square$ Manhattan5-D BilverDollar-D $\square$ Manhattan5-W @ SilverDollar-W

Fig. 3. Changes in leaf superoxide dismutase [SOD (A)] and catalase [CAT (B)] of two perennial ryegrass cultivars (drought-tolerant Manhattan-5 and drought-sensitive Silver Dollar) at days 0,4 , and 8 of deficit irrigation and recovery ay day 4 following re-watering (R4). Bars marked with different letters at a given sampling date are not significantly different based on Fisher's protected least significance difference test at $P=0.05$ ( NS = not significant). Manhattan5-D and Manhattan5-W indicate 'Manhattan-5' under deficit irrigation and well-watered conditions, respectively; SilverDollar-D and SilverDollar-W indicate 'Silver Dollar' under deficit irrigation and well-watered conditions, respectively.

and $100 \mu \mathrm{L}$ enzyme extract. The reaction was started with addition of $10 \mu \mathrm{L} 10 \mathrm{~mm} \mathrm{H}_{2} \mathrm{O}_{2}$. The absorbance of the solution was determined at $290 \mathrm{~nm}$ after $1 \min \left(\epsilon=2.8 \mathrm{~mm}^{-1} \cdot \mathrm{cm}^{-1}\right)$.

Antioxidant isozymes. The procedure of protein extraction was the same as for antioxidant enzymes. The extracts $(15 \mu \mathrm{L})$ for SOD, CAT, and APX were loaded on each gel. Native polyacrylamide gel electrophoresis (PAGE) was performed using a Mini-Protean system (Bio-Rad Laboratories, Hercules, $\mathrm{CA}$ ) at $4{ }^{\circ} \mathrm{C}, 120 \mathrm{~V}$ for $90 \mathrm{~min}$, except that SDS was omitted. For SOD and APX, enzyme extracts were subjected to native PAGE with 10\% resolving gel and 3\% stacking gel and CAT was detected on $7 \%$ resolving gel and $4 \%$ stacking gel.

The total activity of SOD was revealed using the method of Beauchamp and Fridovich (1971) with some modifications. The gels were incubated in $50 \mathrm{~mm}$ potassium phosphate buffer $(\mathrm{pH}=7.5)$ containing $2.5 \mathrm{~mm}$ NBT in the dark for $25 \mathrm{~min}$. After being washed twice with the same buffer, the gels were soaked in $50 \mathrm{~mm}$ potassium phosphate buffer $(\mathrm{pH}=7.5)$ containing $30 \mu \mathrm{M}$ riboflavin and $0.4 \% \mathrm{~N}, \mathrm{~N}$, $\mathrm{N}, \mathrm{N}$-tetramethylethylenediamine (TEMED) in the dark for $40 \mathrm{~min}$. The gels were then illuminated for $10 \mathrm{~min}$ with gentle agitation until appearance of enzyme bands and were transferred to $1 \%(\mathrm{v} / \mathrm{v})$ acetic acid to stop the reaction.

The CAT isozyme staining was performed according to He and Huang (2010) and Woodbury and Stahmann (1971) with modifications. After finishing each run, the gel was washed in three changes of distilled water for a total of $\approx 6 \mathrm{~min}$ to remove the buffer from the gel surface where staining occurred. The gels were incubated in $5 \mathrm{~mm}$ $\mathrm{H}_{2} \mathrm{O}_{2}$ for 10 min in the dark, and then in the stain mixture containing $1 \%(\mathrm{w} / \mathrm{v})$ potassium ferricyanide and $1 \%(\mathrm{w} / \mathrm{v})$ ferric chloride in d.i. $\mathrm{H}_{2} \mathrm{O}$ under $20^{\circ} \mathrm{C}$ until the light yellow bands (CAT isozymes) were visible.

The activity of APX was detected using the method of López-Huertas et al. (1999) with some modifications. The gels were preincubated in $50 \mathrm{~mm}$ sodium phosphate buffer with $4 \mathrm{~mm}$ ascorbate and $2 \mathrm{mM} \mathrm{H}_{2} \mathrm{O}_{2}$ for $20 \mathrm{~min}$. After briefly being washed with $50 \mathrm{~mm}$ potassium phosphate buffer $(\mathrm{pH}=7.0)$, the gels were stained in $50 \mathrm{~mm}$ potassium phosphate buffer ( $\mathrm{pH}=7.8$ ) containing $28 \mathrm{~mm}$ TEMED and $1.25 \mathrm{~mm}$ NBT until the bands were clearly visible. The gels were then washed with distilled water to stop the reaction. The isozyme size was determined based on protein marker.

RNA EXTRACTION AND QUANTITATIVE REVERSE TRANSCRIPTION POLMERASE CHAIN REACTION (RT-PCR). Total RNA was extracted from $150 \mathrm{mg}$ of leaf tissue using RNeasy plant mini RNA kit (Qiagen, Valencia, CA). Genomic DNA was eliminated using RNase-free DNase (Promega, Madison, WI). Synthesis of cDNA and quantitative RT-PCR were performed as described in Fukao and Bailey-Serres (2008). One microgram of total RNA was reversely transcribed with oligo (dT) primer using a cDNA synthesis kit (DyNAmo; Thermo Fisher Scientific, Waltham, MA). Gene-specific primers were synthesized based on the sequences used in Li et al. (2012) and Huang et al. (2014b) (Table 1). Quantitative RT-PCR was conducted in a $15-\mu \mathrm{L}$ reaction using iTaq Universal SYBR Green Supermix (Bio-Rad) in the CFX Connect real-time-PCR detection system (Bio-Rad). Amplification specificity was validated by melt-curve analysis at the end of each PCR experiment. Relative transcript abundance was calculated using the comparative cycle threshold method. Eukaryotic initiation factor 4 alpha $(e I F 1 A)$ gene was used as a normalization control (Huang et al., 2014b).

LEAF ABA AND IAA. Leaf IAA and ABA were extracted according to Edlund et al. (1995) and Zhang et al. (2009) with some modifications. Leaf tissue $(50 \mathrm{mg})$ was ground with a mortar and pestle in liquid $\mathrm{N}_{2}$ and extracted in $1.6 \mathrm{~mL}$ sodium phosphate buffer $(0.05 \mathrm{M}, \mathrm{pH}=7.0)$ containing $0.02 \%$ sodium diethyldithiocarbamate as an antioxidant and the hormones 


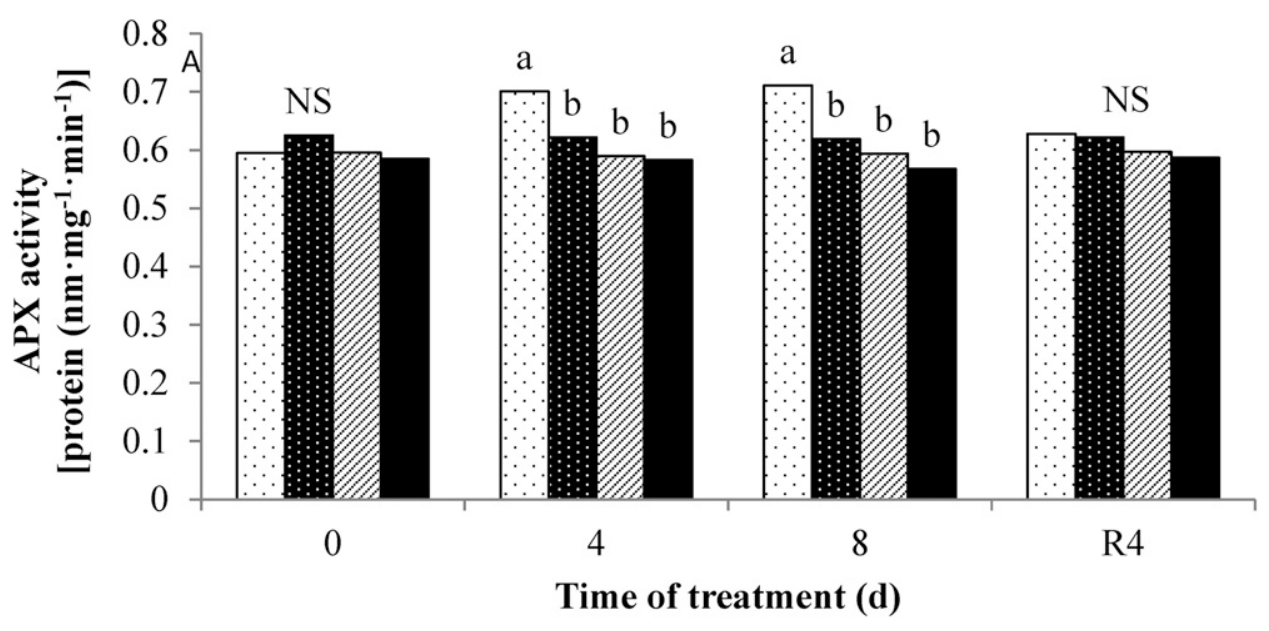

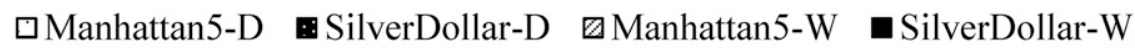

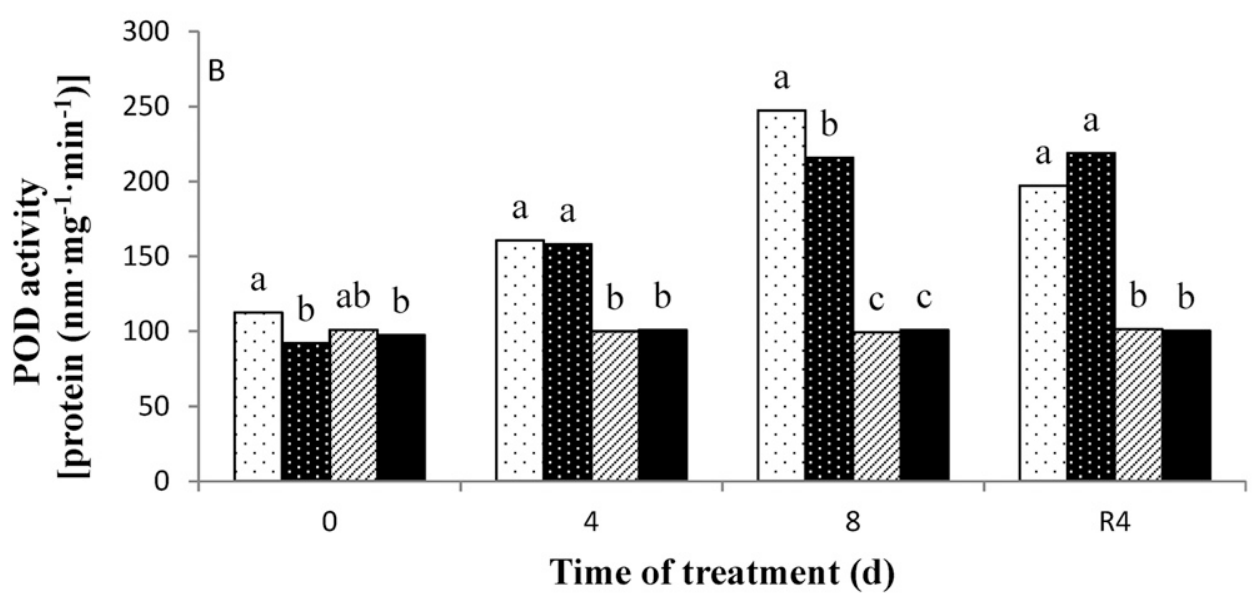

$\square$ Manhattan5-D SilverDollar-D $\square$ Manhattan5-W $\square$ SilverDollar-W

Fig. 4. Changes in leaf ascorbate peroxidase $[\operatorname{APX}(\mathbf{A})]$ and peroxidase [POD (B)] of two perennial ryegrass cultivars (drought-tolerant Manhattan-5 and drought-sensitive Silver Dollar) at days 0, 4, and 8 of deficit irrigation and recovery at day 4 following rewatering (R4). Bars marked with different letters at a given sampling date are not significantly different based on Fisher's protected least significance difference test at $P=0.05$ (NS $=$ not significant). Manhattan5-D and Manhattan5-W indicate 'Manhattan-5' under deficit irrigation and wellwatered conditions, respectively; SilverDollar-D and SilverDollar-W indicate 'Silver Dollar' under deficit irrigation and well-watered conditions, respectively.

were extracted for $1 \mathrm{~h}$ at $4{ }^{\circ} \mathrm{C}$ with shaking. The $\mathrm{C}^{13}$-IAA $(50 \mathrm{ng})$ was added into each sample as an internal standard. The $\mathrm{pH}$ of the samples was adjusted to 2.6 with $1.0 \mathrm{M} \mathrm{HCl}$. The sample was slurried with $150 \mathrm{mg}$ Amberlite XAD-7 (SigmaAldrich, St. Louis, MO) for $30 \mathrm{~min}$. After removal of the buffer, the XAD-7 was washed two times with $1 \mathrm{~mL}$ of $1 \%$ acetic acid before being slurried two times with $1.5 \mathrm{~mL}$ dichloromethane for $30 \mathrm{~min}$ each at $4{ }^{\circ} \mathrm{C}$ (Edlund et al., 1995). The combined dichloromethane fractions were reduced to dryness with $\mathrm{N}_{2}$ gas. Then samples were dissolved in $210 \mu \mathrm{L}$ methanol and diluted with $490 \mathrm{uL}$ d.i. $\mathrm{H}_{2} \mathrm{O}$ containing $0.1 \%$ formic acid. The samples were filtered using an acrodisc $13-\mathrm{mm}$ syringe filter with a 0.2-mm nylon membrane (Fisher Scientific, Pittsburgh, PA),

An Agilent tandem LC-MS/MS system with an ESI sample introduction interface (Agilent, Santa Clara, CA), consisting of 1290 UPLC and 6490 QQQ, was used for analyzing IAA and
ABA in extracts. The HPLC separation was performed on an Agilent Zorbax Extend-C18 analytical (4.6 $\times 50 \mathrm{~mm}, 5 \mu \mathrm{m})$ and guard $(4.6 \times$ $12 \mathrm{~mm}, 5 \mu \mathrm{m})$ columns. The analytes were eluted with water (mobile phase A) and methanol (B) in $0.1 \%$ formic acid in a gradient: $0-4.5 \mathrm{~min}$ $\mathrm{B}$ increasing from $30 \%$ to $80 \%$, $4.5-5$ min $\mathrm{B}$ increasing to $100 \%$, 5-7 min B at $100 \%$, and B decreasing to $30 \%$ at $7.5 \mathrm{~min}$. The injecting volume was $10 \mu \mathrm{L}$ and flow rate was $0.5 \mathrm{~mL} \cdot \mathrm{min}^{-1}$. The column temperature was $40^{\circ} \mathrm{C}$.

The chromatography retention time, precursor ion, fragmental reactions monitored, ionization mode, and collision energies used for each compound are given in Table 2. The $\mathrm{C}^{13}$-labeled IAA $\left(\mathrm{IAA}_{\mathrm{d} 5}\right)$ was used as an internal standard. The source parameters were: nebulizer pressure $310 \mathrm{kPa}$, dry gas temperature $250^{\circ} \mathrm{C}$, sheath gas temperature $200{ }^{\circ} \mathrm{C}$, and gas flow $8 \mathrm{~mL} \cdot \mathrm{min}^{-1}$. IAA and ABA were determined based on retention times and ion products and standards of IAA and ABA.

EXPERIMENTAL DESIGN AND STATISTICAL ANALYSIS. A split plot design was used with soil moisture replacement levels as the main plots and cultivars as the subplots. There were four replicates for each treatment. There was no significant interaction of experiment by treatment, so the data from Expts. 1 and 2 were pooled and the averages of each parameter across the two experiments were used for statistical analysis and presented. Effects of soil moisture, cultivar, and their interactions were analyzed with analysis of variance according to the general linear model using SAS (version 9.3 for Window; SAS Institute, Cary, NC, 2010). The moisture by cultivar interaction for each of the measurements was significant $(P<0.05)$. Comparisons of the four treatments (two soil moisture regimes $\times$ two cultivars) were performed using the Fisher's protected least significance difference test at $P=0.05$.

\section{Results}

SoIL WATER CONTENT. Pressure plate estimates of volumetric soil moisture retention at $-0.01 \mathrm{MPa}$ were $($ mean $\pm \mathrm{SD}) 21.2 \% \pm$ $0.22 \%$ and at $-1.5 \mathrm{MPa}$ were $6.1 \% \pm 0.02 \%$. The capacitanceprobe measurements of in-pot volumetric moisture $(0-8 \mathrm{~cm}$ depth) at day 0 averaged $34.4 \% \pm 0.21 \%$. The pots lost moisture uniformly and no significant differences in soil moisture content were measured between cultivars (data not shown). 

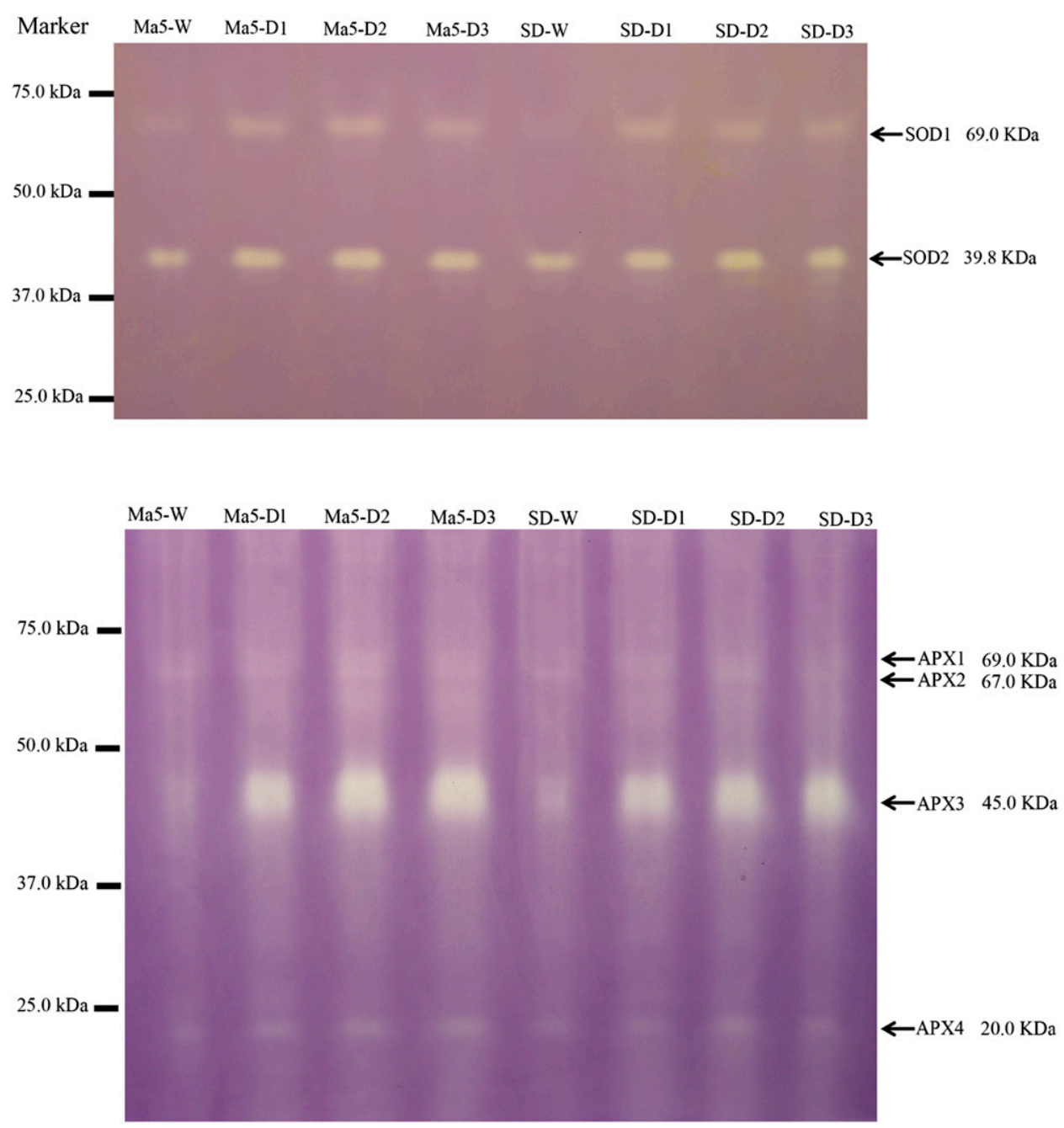

Fig. 5. Changes in superoxide dismutase [SOD (top)] and ascorbate peroxidase [APX (bottom)] isoforms of 'Manhattan-5' and 'Silver Dollar' perennial ryegrass under well-watered and deficit irrigation conditions ( $8 \mathrm{~d}$ ). Equal amounts $(15 \mu \mathrm{L})$ were loaded in each lane: lane $1=$ Manhanttan-5 under well-watered; lane 2, 3, and $4=$ replication 1, 2, and 3 of 'Manhattan-5' under deficit irrigation ( $8 \mathrm{~d}$ ). Lane 5 = 'Silver Dollar' under wellwatered; lane 6, 7, and 8 = replication 1,2, and 3 of 'Silver Dollar' under deficit irrigation ( $8 \mathrm{~d}$ ).

No difference in PE was found between the two cultivars under well-watered conditions.

LEAF MDA CONTENT. MDA is an end product of lipid peroxidation, an indicator of oxidative stress induced by overaccumulation of ROS. Leaf MDA content increased significantly in response to deficit irrigation in the two cultivars by day 8 (Fig. 2B). Greater MDA content in 'Silver Dollar' relative to 'Manhattan-5' was observed at 4 and $8 \mathrm{~d}$. The MDA content in 'Silver Dollar' was $41 \%$ greater than in 'Manhattan-5' at $8 \mathrm{~d}$. MDA content declined after rewatering from $8 \mathrm{~d}$ to $\mathrm{R} 4$. No differences were observed between the two cultivars under well-watered conditions.

Antioxiddant enzyme aCtivity. The activity of SOD declined from 0 to $4 \mathrm{~d}$ and increased from 4 to $8 \mathrm{~d}$ in both cultivars (Fig. 3A). 'Manhat$\tan -5$ ' had greater SOD activity relative to 'Silver Dollar' at days 4,8 , and R4. The SOD activity in 'Manhattan-5' was 22\% higher than that in 'Silver Dollar' at $8 \mathrm{~d}$. Under well-watered conditions, no difference in SOD activity was found between the two cultivars (Fig. 3A).

The activity of CAT increased from 0 to $4 \mathrm{~d}$ in 'Manhattan-5' but not in 'Silver Dollar' (Fig. 3B). 'Manhattan-5' had greater CAT activity relative to 'Silver Dollar' at days 4, 8, and R4. Under wellwatered conditions, no difference in

Capacitance-probe estimates of in-pot volumetric water content declined during the dry-down cycles as follows: $28.6 \% \pm 0.15 \%$ at day $2,18.8 \% \pm 0.06 \%$ at day $4,11.3 \% \pm 0.16 \%$ at day 6 , and $7.5 \% \pm 0.12 \%$ at day 8 . On rewatering, soil moisture content was maintained at $34.4 \% \pm 0.22 \%$ from days 1 to 4 (R4) following rewatering.

Grass Quality. Grass quality declined due to deficit irrigation at $8 \mathrm{~d}$ (Fig. 1A). Drought-tolerant 'Manhattan-5' had a higher quality rating than drought-sensitive 'Silver Dollar' under drought stress $(8 \mathrm{~d})$. Grass quality recovered to similar levels across cultivars after rewatering.

LeAF RWC. Deficit irrigation reduced RWC in both cultivars at $8 \mathrm{~d}$ (Fig. 1B). 'Manhattan-5' had higher RWC than 'Silver Dollar' under deficit irrigation at $8 \mathrm{~d}$. Leaf RWC recovered equivalently after rewatering at R4. No cultivar differences were found in RWC under well-watered conditions.

Canopy PE. Deficit irrigation reduced PE at 4 and $8 \mathrm{~d}$. 'Manhattan-5' had higher PE than 'Silver Dollar' under deficit irrigation at $8 \mathrm{~d}$ (Fig. 2A). Canopy PE recovered to a greater extent for 'Manhattan-5' after rewatering as measured at R4.
CAT activity was found between the two cultivars, except at R4 (Fig. 3B).

The activity of APX increased in response to deficit irrigation in 'Manhattan-5', but not in 'Silver Dollar' (Fig. 4A). The activity of APX was $15 \%$ higher in 'Manhattan-5' relative to 'Silver Dollar' at $8 \mathrm{~d}$. No difference in APX activity was found between the cultivars after rewatering. Under wellwatered conditions, no difference in APX activity was found between the two cultivars (Fig. 4A).

The activity of POD increased in response to deficit irrigation from 0 to $8 \mathrm{~d}$ in both cultivars (Fig. 4B). 'Manhat$\tan -5$ ' had greater POD activity than 'Silver Dollar' at $8 \mathrm{~d}$. The POD activity in 'Manhattan-5' was $15 \%$ greater than that in 'Silver Dollar' under deficit irrigation at $8 \mathrm{~d}$. Under wellwatered conditions, no difference in POD activity was found between the cultivars (Fig. 4B).

Antioxidant Isozymes. Our activity staining visualized two SOD isozymes [SOD1 $(69.0 \mathrm{kDa})$ and SOD2 $(39.8 \mathrm{kDa})$ ] in both cultivars (Fig. 5). SOD1 abundance increased in response to increasing water-deficit treatment in both cultivars. SOD1 in 
'Manhattan-5' had greater abundance than in 'Silver Dollar' (Fig. 5).

Only one isoform of CAT was identified in both cultivars and no difference in CAT abundance was found between the two cultivars (data not shown). Four APX isozymes [APX1 (69.0 kDa), APX2 (67.0 kDa), APX3 (45.0 kDa), and APX4 $(20.0 \mathrm{kDa})$ ] were detected in the two cultivars (Fig. 5). Deficit irrigation increased the abundance of APX1 and APX3 isozymes expression in both cultivars. 'Manhattan-5' had greater abundance of APX3 and APX4 isozymes than 'Silver Dollar'.

Antioxidant Gene EXPRESSION. The level of $\mathrm{Cyt} \mathrm{Cu} / \mathrm{Zn} \mathrm{SOD}$ mRNA increased in response to $8 \mathrm{~d}$ of deficit irrigation in both cultivars (Fig. 6). Expression of $M n S O D$ and $p A P X$ genes were not significantly altered in response to deficit irrigation in the two cultivars. No differences in $\mathrm{Cyt} C u / \mathrm{Zn} S O D, M n S O D$, and $p A P X$ gene expressions were found between the two cultivars under well-watered conditions.

LeAF ABA AND IAA Content. Leaf ABA content increased in response to deficit irrigation in both cultivars, with a greater increase being found in Silver Dollar at $4 \mathrm{~d}$ (Fig. 7A). The ABA content in 'Silver Dollar' was 59\% higher than 'Manhattan-5' at $4 \mathrm{~d}$. Under well-watered conditions, leaf ABA content was similar in both cultivars (Fig. 7A).

Leaf IAA content increased from 4 to $8 \mathrm{~d}$ due to deficit irrigation and declined after rewatering (Fig. 7B). Leaf IAA content was higher in 'Silver Dollar' relative to 'Manhattan-5' at $4 \mathrm{~d}$ (deficit irrigation) and R4 (recovery at $4 \mathrm{~d}$ following rewatering) (Fig. 7B).

\section{Discussion}

The results of this study indicate that deficit irrigation caused cellular and leaf damage to perennial ryegrass as indicated by increased MDA and decreased PE and visual quality. Droughttolerant 'Manhattan-5' had lower MDA and higher PE relative to drought-sensitive 'Silver Dollar'. These results are supported by a previous study by $\mathrm{Yu}$ (2013), which demonstrated that 'Manhattan-4' had greater drought tolerance than 'Silver Dollar' based on the comparison of 18 perennial ryegrass cultivars. Our data suggest that 'Manhattan-5' had less oxidative damage and maintained better photosynthetic function relative to 'Silver Dollar' under water deficit conditions.

There is a broad consensus that antioxidant enzymes such as SOD, APX, CAT, and POD play important roles in the detoxification of ROS accumulated under drought (Noctor et al., 2014; Reddy et al., 2004). Our enzyme assays showed that SOD activity declined and then increased, POD increased in both cultivars, and CAT and APX increased in 'Manhattan-5' in response to deficit irrigation. $\mathrm{Xu}$ et al. (2011) noted that a drought-tolerant cultivar Midnight had higher APX activity than a drought-sensitive cultivar Brilliant in kentucky bluegrass under drought stress. Lu et al. (2008) reported that improved drought tolerance in mutant bermudagrass was related to increased activities of leaf SOD, CAT, and APX. Increases in antioxidant enzyme activity may facilitate the scavenging of ROS and alleviate ROS-induced injury to plant cells under water deficit.

Interestingly, 'Manhattan-5' had higher SOD, CAT, APX, and POD activity relative to 'Silver Dollar' under deficit irrigation at $8 \mathrm{~d}$. This is consistent with the results from previous studies by Man et al. (2011) who showed that
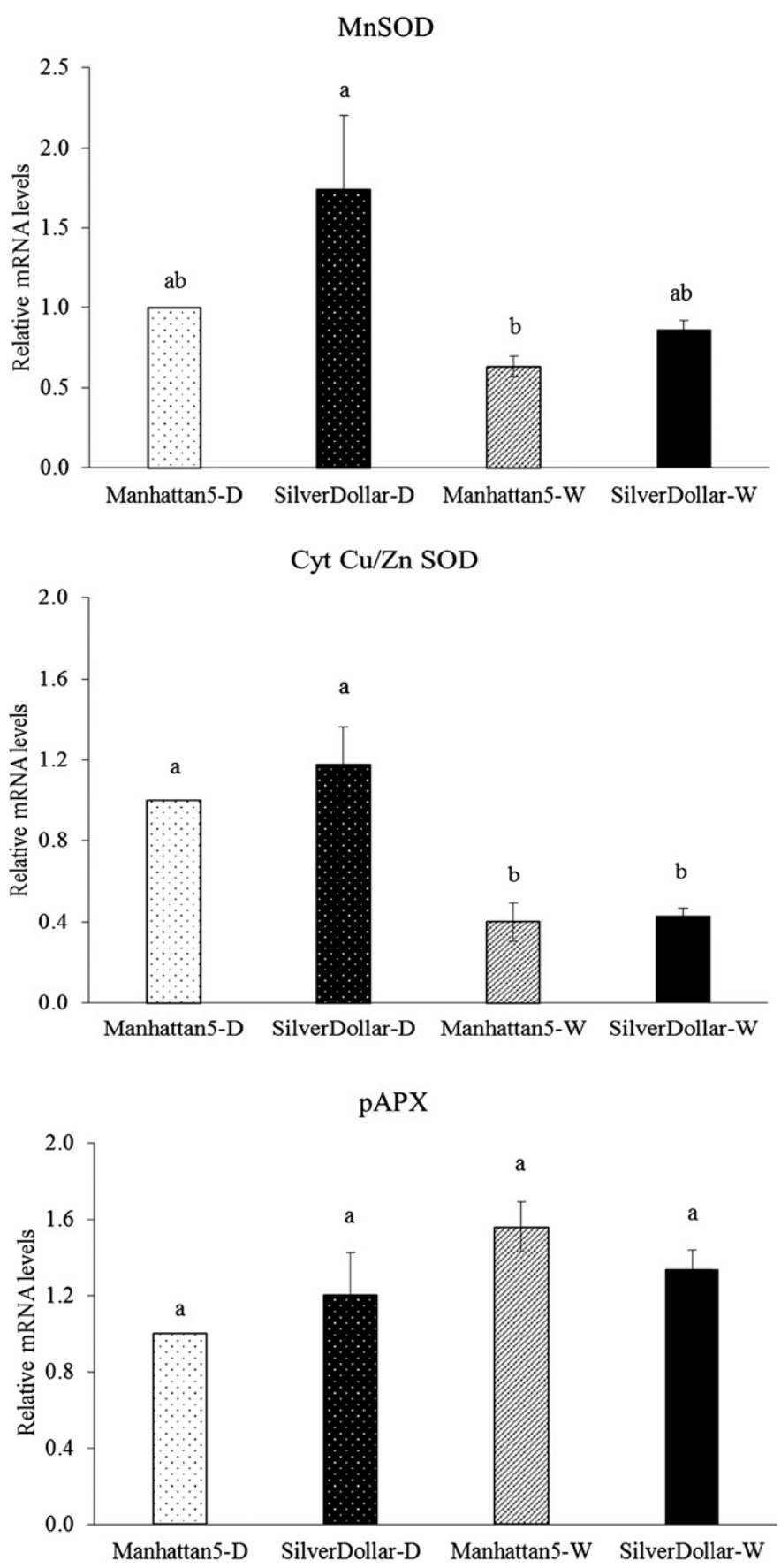

Fig. 6. Relative transcript levels of leaf $\mathrm{Cyt} \mathrm{Cu} / \mathrm{Zn}$ superoxide dismutase $(C y t$ $C u / Z n S O D)$, manganese superoxide dismutase (Mn SOD), and ascorbate peroxidase $(p A P X)$ genes of two perennial ryegrass cultivars (drought-tolerant Manhattan-5 and drought-sensitive Silver Dollar) under well-watered and deficit irrigation $(8 \mathrm{~d})$. The relative level of each mRNA was calculated by comparison with drought-stressed 'Manhattan-5'. The data represent means \pm SE from three biological replicates. Bars not sharing the same letter are significantly different based on Fisher's protected least significance difference test at $P<0.05$. Manhattan5-D and Manhattan5-W indicate 'Manhattan-5' under deficit irrigation and well-watered conditions, respectively; SilverDollar-D and SilverDollar-W indicate 'Silver Dollar' under deficit irrigation and wellwatered conditions, respectively.

a drought-tolerant tall fescue cultivar had higher antioxidant enzyme activity than a drought-sensitive cultivar. Several studies indicate that cultivar differences in abiotic stress tolerance may partially result from constitutive antioxidant 


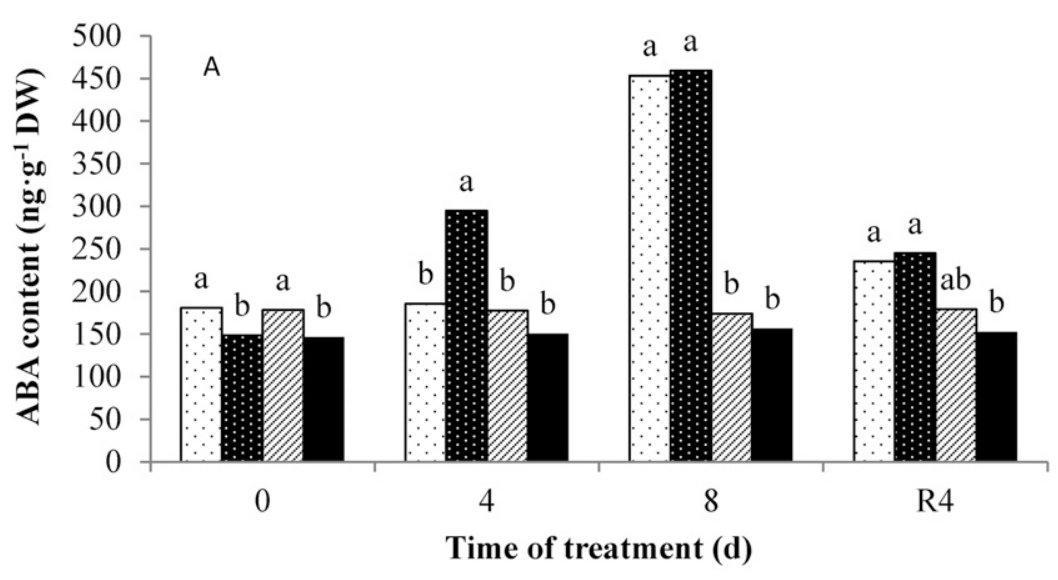

$\square$ Manhattan5-D a SilverDollar-D ๒Manhattan5-W @ SilverDollar-W

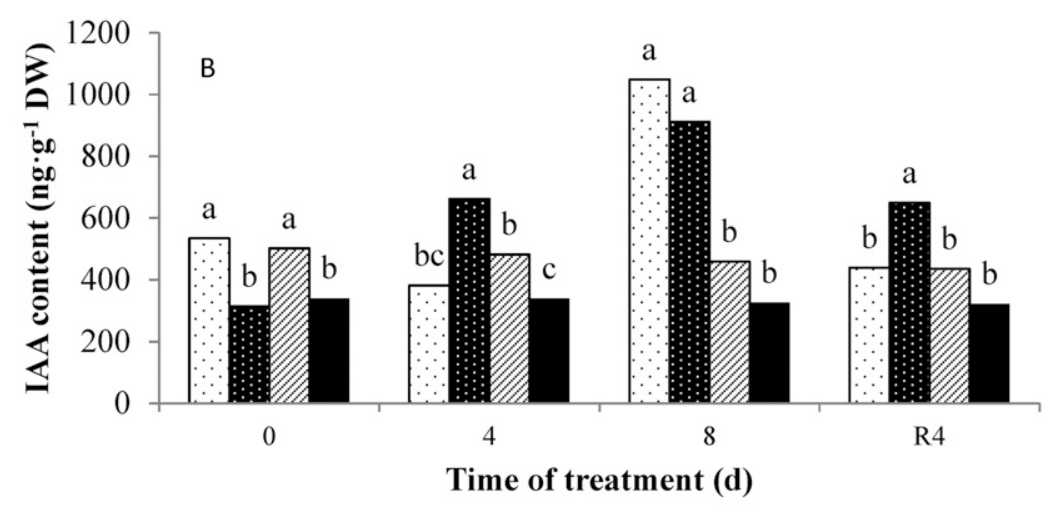

\section{$\square$ Manhattan5-D a SilverDollar-D $\square$ Manhattan5-W $\square$ SilverDollar-W}

Fig. 7. Changes in leaf abscisic acid [ABA (A)] and indole-3-acetic acid [IAA (B)] content of two perennial ryegrass cultivars (drought-tolerant Manhattan-5 and drought-sensitive Silver Dollar) at days 0,4 , and 8 of deficit irrigation and recovery at day 4 following rewatering (R4). Bars marked with different letters at a given sampling date are not significantly different based on Fisher's protected least significance difference test at $P=0.05$; Ns $=$ not significant. Manhattan5-D and Manhattan5-W indicate 'Manhattan-5' under deficit irrigation and well-watered conditions, respectively; SilverDollar-D and SilverDollar-W indicate 'Silver Dollar' under deficit irrigation and well-watered conditions, respectively.

enzyme activities (Stepien and Klobus, 2005; Türkan et al., 2005). SOD and CAT are two major ROS-scavenging enzymes (Huang et al., 2014a). APX and POD scavenge $\mathrm{H}_{2} \mathrm{O}_{2}$ and reduce ROS toxicity. In this study, 'Manhattan-5' had greater APX and POD activity than 'Silver Dollar' under deficit irrigation. This is consistent with $\mathrm{Hu}$ et al. (2012) who reported that a salt-tolerant perennial ryegrass cultivar had higher APX and POD activity than a salt-sensitive cultivar under salt stress. The results of our study suggest that drought-tolerant cultivars may have greater ROS-scavenging capacity to suppress ROS-induced injury during abiotic stress.

Of two SOD isozymes detected, the level of SOD1 increased in response to deficit irrigation in both cultivars. Salekjalali et al. (2012) found four SOD isozymes and drought stress increased abundance of two isozymes in barley (Hordeum vulgare L.). SOD1 in 'Manhattan-5' showed greater abundance than in 'Silver Dollar' (Fig. 5A). In perennial ryegrass, SOD isozymes visualized by activity staining have not been categorized into $\mathrm{Fe} S \mathrm{SOD}, \mathrm{Cu} / \mathrm{Zn}$ SOD, or Mn SOD types. Thus, the identity of SOD1 detected in this study is unknown. However, increased abundance of SOD1 isozyme by deficit irrigation was consistent with upregulation of $C u / Z n S O D$ gene in the two cultivars.

In this study, four APX isozymes were detected in the two cultivars (Fig. 5B). Deficit irrigation increased the abundance of APX3 and APX4 isozymes expression in the two cultivars. Salekjalali et al. (2012) detected six APX isozymes and found that drought stress increased expression of only one isozyme in barley. In our study, 'Manhattan-5' showed greater abundance of APX3 and APX4 isozymes than 'Silver Dollar'. Enzyme isoforms could be more sensitive or meaningful for interpreting plant responses to deficit irrigation compared with total activity changes because different isoforms may function uniquely due to their distinct properties, such as being stress inducible or not, and having different subcellular locations (Apel and Hirt, 2004; Blokhina et al., 2003). Our results suggest that APX activity may be more effective in scavenging $\mathrm{H}_{2} \mathrm{O}_{2}$ under deficit irrigation relative to CAT whose isozyme abundance remained unchanged. Our results indicate that the drought-tolerant cultivar Manhattan-5 most likely had greater ability to scavenge ROS than the drought-sensitive cultivar Silver Dollar.

Quantitative RT-PCR analysis revealed that transcript accumulation of $\mathrm{Cyt} C \mathrm{Cu} / \mathrm{Zn}$ $S O D$ increased in response to $8 \mathrm{~d}$ of deficit irrigation, whereas the abundance of $M n$ $S O D$ and $p A P X$ mRNAs was not significantly altered (Fig. 6). Upregulation of $C y t \mathrm{Cu} / \mathrm{Zn}$ $S O D$ gene during water-deficit treatment is consistent with isozyme analysis and enzyme activity assay results (Figs. 3 and 5). Xu et al. (2011) reported that drought stress increased $C y t C u / Z n S O D$ and $C y t A P X$ gene expression in kentucky bluegrass. Bian and Jiang (2009) noted that drought stress inhibited $C y t C u / Z n S O D$ gene expression but did not impact $C y t A P X$ gene expression in kentucky bluegrass.

In this study, no difference in $C y t C u / Z n S O D, M n S O D$, and $p A P X$ gene expression was found between the two cultivars. A similar result was found in kentucky bluegrass (Xu et al., 2011). It is known that SOD and APX are encoded by gene families $\{\mathrm{e}$. g., eight $S O D$ and nine $A P X$ genes in arabidopsis [Arabidopsis thaliana (L.) Heynh] $\}$ and located in various organelles such as cytosol, chloroplast, mitochondria, or peroxisome (Mittler et al., 2004). Distinct activities of these enzymes in the two cultivars during drought may result from differential expression of other $S O D$ and $A P X$ genes that were not analyzed in this study. Alternatively, activities of these antioxidant enzymes may be controlled at post-transcriptional, translational, and post-translational levels.

Plant hormone metabolism is closely associated with plant drought tolerance (Man et al., 2011; Zhang et al., 2012). The results of this study showed that ABA content increased in response to deficit irrigation, with greater $\mathrm{ABA}$ content in 
'Silver Dollar' relative to 'Manhattan-5' at $4 \mathrm{~d}$. Man et al. (2011) reported that ABA content drastically increased at $10 \mathrm{~d}$ of drought stress in tall fescue with the drought-tolerant cultivar having greater $\mathrm{ABA}$ content relative to the drought-sensitive one. However, our results showed that the drought-tolerant cultivar had lower levels of ABA than the drought-sensitive one under deficit irrigation at early stage $(4 \mathrm{~d})$, but not late stage ( $8 \mathrm{~d}$ ) of water deficit. Although, ABA is a key signaling molecule regulating various acclimation responses to drought, a subset of genes associated with drought adaptation are induced through ABA-independent pathways in arabidopsis and rice [Oryza sativa L. (Shinozaki and Yamaguchi-Shinozaki, 2007; Zhu et al., 2002)]. Distinct drought tolerance between two perennial ryegrass cultivars may result from differential regulation of ABA-independent pathways involved in stress adaptation. A lower level of endogenous ABA in 'Manhattan-5' may result in improved acclimation to gradual soil moisture limitation. The abundance of ABA is associated with stomatal closure. As drought progressed, 'Manhattan-5' may have had better gas exchange and less oxidative stress because of lower levels of ABA relative to 'Silver Dollar' at $4 \mathrm{~d}$. The results of this study suggest that greater drought tolerance in 'Manhattan-5' relative to 'Silver Dollar' may be associated with its early stage lower level of ABA coupled with higher antioxidant defense capacity.

The results of this study showed that IAA increased in response to deficit irrigation in both cultivars, but that there were no cultivar differences in IAA content at day 8 . Krishnan and Merewitz (2015) also indicated that drought stress increased IAA content in kentucky bluegrass. Pustovoitova and Zholkevich (1992) suggested that not only ABA, but also IAA are involved in the development of defense responses during adaptation to drought. It was reported that IAA can delay plant senescence under stress (Zhang et al., 2009). However, Man et al. (2011) reported that IAA in tall fescue declined under severe drought. The variation in IAA responses to drought in different studies may be related to drought stress intensity, duration, and plant species. Leaf IAA content may increase under moderate water deficit, and may decline under prolonged severe drought.

Krishnan and Merewitz (2015) noted that the kentucky bluegrass with better gas exchange (higher stomatal conductance and transpiration rate) had less cell membrane damage (lower electrolyte leakage) and greater photosynthetic rate under drought stress. Zhang et al. (2013) showed that corn (Zea mays L.) plants with a lower level of ABA had greater PE and SOD activity. Plants with a higher level of ABA may induce stomatal closure and inhibit gas exchange, resulting in oxidative injury of cells due to excess ROS. It is possible that plants with a lower level of ABA but greater IAA may improve gas exchange, antioxidant defense systems, and delay leaf senescence because of less ROS accumulation under drought stress.

In summary, our data clearly indicate that the two cultivars differed in adaptation to deficit irrigation. The previously categorized drought-tolerant 'Manhattan-5' had less MDA content and higher PE relative to drought-sensitive 'Silver Dollar' under deficit irrigation. SOD activity declined and then increased during deficit irrigation. 'Manhattan-5' had higher SOD activity and greater abundance of SOD1 isozyme than 'Silver Dollar' under deficit irrigation. CAT and APX activity increased in 'Manhattan-5', but not in 'Silver Dollar', under deficit irrigation. 'Manhattan-5' had higher CAT, APX, and POD activity than 'Silver Dollar' during deficit irrigation. Deficit irrigation increased $C y t C u / Z n S O D$ gene expression, but did not alter $M n S O D$ and $p A P X$ gene expression. Deficit irrigation increased leaf ABA and IAA content in both cultivars, with Silver Dollar having greater ABA content than Manhattan-5. Changes in ABA level as soil moisture becomes limiting may regulate stomatal opening and oxidative stress, which may trigger antioxidant defense responses. Our results indicate that antioxidant and hormonal metabolic adjustments could be associated with drought tolerance in perennial ryegrass. The data suggest that selection and use of cultivars with greater antioxidant enzyme activities and more abundant isozymes under deficit irrigation may be a practical approach to improve perennial ryegrass drought tolerance and quality.

\section{Literature Cited}

Apel, K. and H. Hirt. 2004. Reactive oxygen species: Metabolism, oxidative stress, and signal transduction. Annu. Rev. Plant Biol. 55:373-399.

Beauchamp, C. and I. Fridovich. 1971. I. Superoxide dismutase: Improved assays and an assay applicable to acrylamide gels. Anal. Biochem. 44:276-287.

Bian, S. and Y. Jiang. 2009. Reactive oxygen species, antioxidant enzyme activities and gene expression patterns in leaves and roots of kentucky bluegrass in response to drought stress and recovery. Sci. Hort. 120:264-270.

Blokhina, O., E. Virolainen, and K.V. Fagerstedt. 2003. Antioxidants, oxidative damage and oxygen deprivation stress: A review. Ann. Bot. (Lond.) 91:179-194.

Bradford, M. 1976. A rapid and sensitive method for the quantitation of microgram quantities of protein utilizing the principle of proteindye binding. Anal. Biochem. 72:248-254.

Chance, B. and A.C. Maehly. 1955. Assay of catalases and peroxidases. Methods Enzymol. 2:764-775.

DaCosta, M. and B. Huang. 2007. Changes in antioxidant enzyme activities and lipid peroxidation for bentgrass species in response to drought stress. J. Amer. Soc. Hort. Sci. 132:319-326.

Edlund, A., S. Eklof, B. Sundberg, T. Moritz, and G. Sandberg. 1995. A microscale technique for gas chromatography-mass spectrometry measurements of picogram amounts of indole-3- acetic acid in plant tissues. Plant Physiol. 108:1043-1047.

Fukao, T. and J. Bailey-Serres. 2008. Submergence tolerance conferred by Sub1A is mediated by SLR1 and SLRL1 restriction of gibberellin responses in rice. Proc. Natl. Acad. Sci. USA 105:16814-16819.

Giannopolitis, C.N. and S.K. Ries. 1977. Superoxide dismutase. 1. Occurrence in higher plants. Plant Physiol. 59:309-314.

He, Y.L. and B. Huang. 2010. Differential responses to heat stress in activities and isozymes of four antioxidant enzymes for two cultivars of kentucky bluegrass contrasting in heat tolerance. J. Amer. Soc. Hort. Sci. 135:116-124.

Hodges, D.M., J.M. Delong, C.F. Forney, and R. Prange. 1999. Improving the thiobarbituric acid-reactive-substances assay for estimating lipid peroxidation in plant tissues containing anthocyanin and other interfering compounds. Planta 207:604-611.

Hu, L., H. Li, H. Pang, and J. Fu. 2012. Response of antioxidant gene, protein and enzymes to salinity stress in two genotypes of perennial ryegrass (Lolium perenne L.) differing in salt tolerance. J. Plant Physiol. 169:146-156.

Huang, B., M. DaCosta, and Y. Jiang. 2014a. Research advances in mechanisms of grass tolerance to abiotic stresses: From physiology to molecular biology. Crit. Rev. Plant Sci. 33:141-189.

Huang, L., H. Yan, X. Jiang, G. Yin, X. Zhang, X. Qi, Y. Zhang, Y. Yan, X. Ma, and Y. Peng. 2014b. Identification of candidate 
reference genes in perennial ryegrass for quantitative RT-PCR under various abiotic stress conditions. PLoS One 9:e93724.

Jiang, Y. and B. Huang. 2001. Drought and heat stress injury to two cool-season grasses in relation to antioxidant metabolism and lipid peroxidation. Crop Sci. 41:436-442.

Kim, Y., S. Lim, S. Han, J. Lee, W. Song, and J. Bang. 2007. Differential expression of 10 sweet potato peroxidases in response to sulfur dioxide, ozone, and ultraviolet radiation. Plant Physiol. Biochem. 45:908-914.

Klute, A. 1983. Water capacity, p. 273-278. In: C.A. Black (ed.). Methods of soil analysis. Physiological and mineralogical properties, including statistics of measurement and sampling. Amer. Soc. Agron. Monogr. 9, Part I, Amer. Soc. Agron., Madison, WI.

Krishnan, S. and E.B. Merewitz. 2015. Drought stress and trinexapacethyl modify photohormone content within kentucky bluegrass leaves. J. Plant Growth Regulat. 34:1-12.

Krishnan, S., K. Laskowski, V. Shukla, and E.B. Merewitz. 2013. Mitigation of drought stress damage by exogenous application of a non-protein amino acid g-aminobutyric acid on perennial ryegrass. J. Amer. Soc. Hort. Sci. 138:358-366.

Li, H., H. Luo, D. Li, T. Hu, and J. Fu. 2012. Antioxidant enzyme activity and gene expression in response to lead stress in perennial ryegrass. J. Amer. Soc. Hort. Sci. 137:80-85.

Lu, S., Z. Wang, Y. Niu, Z. Guo, and B. Huang. 2008. Antioxidant responses of radiation-induced dwarf mutants of bermudagrass to drought stress. J. Amer. Soc. Hort. Sci. 133:360-366.

López-Huertas, E., F.J. Corpas, L.M. Sandalio, and L.A. del Río. 1999. Characterization of membrane polypeptides from pea leaf peroxisomes involved in superoxide radical generation. Biochem. J. 337:531-536.

Man, D., Y.X. Bao, L.B. Han, and X. Zhang. 2011. Drought tolerance associated with proline and hormone metabolism in two tall fescue cultivars. HortScience 46:1027-1032.

Mittler, R., S. Vanderauwera, M. Gollery, and F. van Breusegem. 2004. Reactive oxygen gene network of plants. Trends Plant Sci. 9:490-498.

Mullineaux, P.M. and G.P. Creissen. 1997. Glutathione reductase: Regulation and role in oxidative stress, p. 667-713. In: J.G. Scandalios (ed.). Oxidative stress and the molecular biology of antioxidant defenses. Cold Spring Harbor Lab. Press, New York, NY.

Noctor, G., A. Mhamdi, and C.H. Foyer. 2014. The role of reactive oxygen metabolism in drought: Not so cut and dried. Plant Physiol. 164:1636-1648.

Pinhero, R.G., M.V. Rao, G. Paliyath, D.P. Murr, and R.A. Fletcher. 1997. Changes in activities of antioxidant enzymes and their relationship to genetic and paclobutrazol-induced chilling tolerance of maize seedlings. Plant Physiol. 114:695-704.

Pustovoitova, T.N. and V.N. Zholkevich. 1992. Basic trends in the investigation of heat effects on physiological processes in plants. Fiziologiya i Biokhimiya Kul'turnykh Rastenii 24:14-27.

Reddy, A.R., K.V. Chaitanya, and M. Vivekanandan. 2004. Droughtinduced responses of photosynthesis and antioxidant metabolism in higher plants. J. Plant Physiol. 161:1189-1202.

Salekjalali, M., R. Haddad, and B. Jafari. 2012. Effects of soil water shortage on the activity of antioxidant enzymes and the contents of chlorophylls and proteins in barley. Amer-Eurasian J. Agr. Environ. Sci. 12:57-63.

Shinozaki, K. and K. Yamaguchi-Shinozaki. 2007. Gene networks involved in drought stress response and tolerance. J. Expt. Bot. 58:221-227.

Stepien, P. and G. Klobus. 2005. Antioxidant defense in the leaves of C3 and C4 plants under salinity stress. Physiol. Plant. 125:31-40.

Strivastava, L.M. 2002. Plant growth and development: Hormones and environment. Academic Press, San Diego, CA.

Türkan, I., M. Bor, F.O. Zdemir, and H. Koca. 2005. Differential responses of lipid peroxidation and antioxidants in the leaves of drought-tolerant $P$. acutifolius Gray and drought-sensitive $P$. vulgaris $\mathrm{L}$. subjected to polyethylene glycol mediated water stress. Plant Sci. 168:223-231.

Wang, K., X. Zhang, and E.H. Ervin. 2012. Antioxidative responses in roots and shoots of creeping bentgrass under high temperature: Effects of nitrogen and cytokinin. J. Plant Physiol. 169:492-500.

Woodbury, W., A.K. Spencer, and M.A. Stahmann. 1971. An improved procedure using ferricyanide for detecting catalase isozymes. Anal. Biochem. 44:301-305.

Xiong, L.M., K.S. Schumaker, and J.K. Zhu. 2002. Cell signaling during cold, drought, and salt stress. Plant Cell 14:S165-S183.

$\mathrm{Xu}$, L.X., L.B. Han, and B. Huang. 2011. Antioxidant enzyme activities and gene expression patterns in leaves of kentucky bluegrass in response to drought and post-drought recovery. J. Amer. Soc. Hort. Sci. 136:247-255.

$\mathrm{Yu}, \mathrm{X}$. 2013. Association of candidate genes with drought tolerant traits in diverse perennial ryegrass accessions. Diss., Purdue Univ., West Lafayette, IN.

Yu, X., G. Bai, S. Liu, Y. Wang, D.S. Richmond, P.M. Pijut, S.A. Jackson, J. Yu, and Y. Jiang. 2013. Association of candidate genes with drought tolerant traits in diverse perennial ryegrass accessions. J. Expt. Bot. 64:1537-1551.

Zhang, J. and M.B. Kirkham. 1996. Antioxidant responses to drought in sunflower and sorghum seedlings. New Phytol. 132:361-373.

Zhang, X. and E.H. Ervin. 2004. Cytokinin-containing seaweed and humic acid extracts associated with creeping bentgrass leaf cytokinins and drought resistance. Crop Sci. 44:1737-1745.

Zhang, X.Z. and E.H. Ervin. 2008. Impact of seaweed extract-based cytokinins and zeatin riboside on creeping bentgrass heat tolerance. Crop Sci. 48:364-370.

Zhang, X.Z., E.H. Ervin, G.K. Evanylo, and K.C. Haering. 2009. Impact of biosolids on hormone metabolism in drought-stressed tall fescue. Crop Sci. 49:1893-1901.

Zhang, X., E.H. Ervin, G.K. Evanylo, J. Li, and K. Harich. 2013. Corn and soybean hormone and antioxidant metabolism responses to biosolids under two cropping systems. Crop Sci. 53:2079-2089.

Zhang, X.Z., E.H. Ervin, and R.E. Schmidt. 2005. The role of leaf pigment and antioxidant levels in UV-B resistance of dark-and light-green kentucky bluegrass cultivars. J. Amer. Soc. Hort. Sci. 130:836-841.

Zhang, X., D. Zhou, E.H. Ervin, G.K. Evanylo, D. Cataldi, and J. Li. 2012. Biosolids impact antioxidant metabolism associated with drought tolerance in tall fescue. HortScience 47:1550-1555.

Zhu, J.K. 2002. Salt and drought stress signal transduction in plants. Annu. Rev. Plant Biol. 53:247-273. 